\author{
UDC 324.131.67:622.23/.24:[624.131.63]
}

\author{
A. MENEYLYUK ${ }^{1 *}$, A. PETROVSKYI ${ }^{2}$, A. BORISOV ${ }^{3}$, I. BABIJ $^{4}$ \\ ${ }^{1 *}$ Odessa State Academy of Civil Engineering and Architecture, 4 Didrihson st., Odessa, Ukraine, 65029, \\ tel. +38(048) 72361 51, e-mail pr.mai@mail.ru, ORCID 0000-0002-1007-309X \\ ${ }^{2}$ Odessa State Academy of Civil Engineering and Architecture, 4 Didrihson st., Odessa, Ukraine, 65029, \\ e-mail paf2012@ukr.net, ORCID 0000-0001-9548-1959 \\ ${ }^{3}$ Odessa State Academy of Civil Engineering and Architecture, 4 Didrihson st., Odessa, Ukraine, 65029, \\ tel. +38 (094) 94920 83, e-mail etinvest@gmail.com, ORCID 0000-0001-6930-3243 \\ ${ }^{4}$ Odessa State Academy of Civil Engineering and Architecture, 4 Didrihson st., Odessa, Ukraine, 65029, \\ tel. +38 (094) 99709 69, e-mail igor_babiy76@mail.ru, ORCID 0000-0001-8650-1751
}

\title{
DEPENDENCE OF SOIL HYDRAULIC CONDUCTIVITY OF THE ADOPTED TECHNOLOGICAL SOLUTIONS
}

Purpose. The aim of this study is to construct experimental and statistical dependencies filtration coefficient of the protected ground, formed by means of horizontal directional drilling, from technological factors. Methodology. Synthesis, analysis, mathematical methods. Findings. Analytical and image filtering coefficient depending on soil following technological factors: duration of injection, which is created using impervious screen bentonite powder concentration per unit volume of hardening mortar, and the discharge pressure (discharge) of the solution into soil. Originality. The regularities of the influence of technological factors (pressure, injection time and the characteristics of injection solutions) on the screen filtration coefficient. Practical value. The practical significance of the results is the development of new technologies to protect the underground space from pollution in soils with solids and lack of impermeable layer on the depth attainable.

Keywords: impervious protective screens; horizontal directional drilling; bentonite; soil filtration coefficient; Experimental statistical modeling

\section{Introduction}

Analysis of the problems arising from the disposal of the consequences of the Chernobyl accident showed that the scale of the impact and the necessary of financial and technical resources are playing a dominant role in the localization of pollution and in the reduction of emission of radioactive substances into the environment $[1,2]$. The arrangement of anti-contagious protective shields by horizontal directional drilling method can be used for protection of groundwater from migration of contaminants. Numerous methods help to build the impervious underground shields, but their analysis showed low economic and environmental performance. According to these criteria, the use of horizontal directional drilling is preferred. The present study has a social significance, as it will allow protecting the population from the consequences of contamination by radionuclide contaminated water.

\section{The analysis of the literature}

As a result of the analysis of known sources on the subject it is concluded that the existing methods of the anti-contagious shields arrangement are not effective for the localization of radioactive waste [311]. In recent years, several attempts were made to develop an efficient technology for such works [79], but the use of horizontal directional drilling for groundwater protection shields can be more promising from an economic or technological perspective.

\section{The purpose and objectives of the study}

The aim of the study is to construct experimental and statistical dependencies of soil filtration coefficient of the shield, formed by horizontal directional drilling, from technological factors. In accordance with the purpose of the following research several objectives were formulated:

1. To carry out the laboratory research of arrangement of protective shield by horizontal directional drilling with varying technological parameters of mortar injection.

2. To build the experimental statistical dependencies of shield filtration coefficient from technological factors by regression analysis of laboratory

(C) A. Meneylyuk, A. Petrovskyi, A. Borisov, I. Babij, 2016 
results with the help of «Compex» software [12, $13]$.

3. To determine the nature and extent of the influence of technological factors on the filtration rate of shield made by injection.

Algorithm of the study is shown below:

1. Statement of research problem.

2. Substantiation of work areas.

3. Analysis of the known sources on the research subject.

4. Development of methods for solving the problems and the creation of the necessary laboratory equipment.

5. Obtaining experimental data to study the parameters of technological modes of injection.

6. Processing and analysis of the experimental results.

\section{Main part}

Since the main feature of impervious screen is its hydrophobicity, which is ability not to let through the groundwater, it was decided to use such a key indicator of physical characteristic of soil as a filtration coefficient.

The modern technology of horizontal directional drilling was combined with injection process, which allows forming impervious horizontal shields for contaminated sites. To simulate this, the laboratory bench was produced which shows section perpendicular to the drill axis, wherein an injection mortar is distributed at different distance away from the input under the influence of the operating parameters. Singling out the middle part of the section, you can get an idea about the nature of soil filtration coefficient change.

The factors that have the greatest impact on the indicator have been identified:

$X_{1}$ - bentonite powder concentration per unit of volume of hardening mortar, which changes a sandy soil filtration property. This factor is important because the bentonite-containing mortar prevents the penetration of contaminated water through injected ground. Considering this, the concentration of the bentonite should be sufficient to form the shield, which has a maximum capacity of hydrophobicity. However, there is a limiting factor - viscosity of the injection mortar, which affects the penetration of material into the gaps between the fine particles of a sandy ground. According to sources considered, the permissible viscosity for clay and cement mortars is between 26 and $43 \mathrm{sec}$. The viscosity was determined by viscometer "Marsh Funnel" with volume of $1000 \mathrm{ml}$.

$X_{2}$ - discharge pressure (supply) of injection mortar in the base soil. Discharge pressure affects the range of injection mortar spread in soil. This factor is very important in economic terms, as modern industrial pumps can achieve more than 100 bar pressures, at the same time allowing you to increase the distance between the horizontally drilled wells, which reduces the cost of the project.

$X_{3}$ - the duration of mortar supply, by which a shield is formed. Time factor could allow establishing a direct proportional relationship between the injection time and the concentration of active substances which affects the properties of impervious soil shield.

Laboratory bench, which simulates the spread of an injection mortar in the injected soil area, has been used in experimental studies. Under the influence of variable combinations of technological parameters the injection mortar forms a model of the protective shield with the different let-through ability.

Measuring the value of soil filtration coefficient in a certain section of the laboratory bench helps to determine dependency of the impervious properties of the shield from the factor combination used.

The processing of the received experimental results (Tab. 1) is performed by regression analysis method using «Compex» software [12, 13].

As a result of this analysis the experimental statistical model of filtration rate dependence from technological parameters of shield arrangement was built (form. 1).

$$
\begin{gathered}
\text { SFC }(\text { m. per day) }=0,105+\bullet+0,212 \\
\mathrm{X}_{1}^{2}+0,123 \mathrm{X}_{1} \mathrm{X}_{2}-0,064 \mathrm{X}_{1} \mathrm{X}_{3} \\
-0,087 \mathrm{X}_{2}+\bullet+\bullet+\bullet+\bullet
\end{gathered}
$$

The factor impact estimations, deemed indistinguishable from zero, are marked by points in this formula.

Fig. 1 shows the ranking of the degree of influence of variable factors on the indicator.

The greatest influence on the filtration coefficient in the area of maximum indicator values has two factors in approximately the same degree: the concentration of bentonite powder and discharge pressure of mortar. At the same time, the duration of mortar supply does not play such a significant role in the change of the indicator. 
The plan and the results of experimental laboratory studies

\begin{tabular}{|c|c|c|c|c|c|c|c|}
\hline \multirow[b]{3}{*}{ No } & \multicolumn{3}{|c|}{ Full-scale variables } & \multicolumn{3}{|c|}{ Coded variables } & \multirow{3}{*}{$\begin{array}{c}\text { Soil filtration } \\
\text { coefficient } \\
\text { (SFC), meter } \\
\text { per day }\end{array}$} \\
\hline & $X_{1}$ & $X_{2}$ & $X_{3}$ & $X_{1}$ & $X_{2}$ & $X_{3}$ & \\
\hline & $\begin{array}{c}\text { Bentonite } \\
\text { powder } \\
\text { concentration } \\
\text { grams per liter }\end{array}$ & $\begin{array}{l}\text { Discharge } \\
\text { pressure of } \\
\text { mortar, atm. }\end{array}$ & $\begin{array}{l}\text { Duration of } \\
\text { mortar supply, } \\
\text { min. }\end{array}$ & $\begin{array}{c}\text { Bentonite } \\
\text { powder } \\
\text { concentration } \\
\text { grams }\end{array}$ & $\begin{array}{l}\text { Discharge } \\
\text { pressure of } \\
\text { mortar, atm. }\end{array}$ & $\begin{array}{l}\text { Duration of } \\
\text { mortar } \\
\text { supply, min. }\end{array}$ & \\
\hline 1 & 2 & 3 & 4 & 5 & 6 & 7 & 8 \\
\hline 1. & 70 & 5 & 110 & 1 & 1 & 1 & 0,37114 \\
\hline 2. & 70 & 5 & 10 & 1 & 1 & -1 & 0,26929 \\
\hline 3. & 70 & 2 & 110 & 1 & -1 & 1 & 0,21114 \\
\hline 4. & 10 & 5 & 110 & -1 & 1 & 1 & 0,07526 \\
\hline 5. & 70 & 2 & 10 & 1 & -1 & -1 & 0,40124 \\
\hline 6. & 10 & 5 & 10 & -1 & 1 & -1 & 0,08985 \\
\hline 7. & 10 & 2 & 110 & -1 & -1 & 1 & 0,80065 \\
\hline 8. & 10 & 2 & 10 & -1 & -1 & -1 & 0,36041 \\
\hline 9. & 70 & 3 & 60 & 1 & $-0,33$ & 0 & 0,34387 \\
\hline 10. & 10 & 3 & 60 & -1 & $-0,33$ & 0 & 0,29899 \\
\hline 11. & 40 & 5 & 60 & 0 & 1 & 0 & 0,15554 \\
\hline 12. & 40 & 2 & 60 & 0 & -1 & 0 & 0,08977 \\
\hline 13. & 40 & 3 & 110 & 0 & $-0,33$ & 1 & 0,14669 \\
\hline 14. & 40 & 3 & 10 & 0 & $-0,33$ & -1 & 0,17049 \\
\hline 15. & 40 & 3 & 60 & 0 & $-0,33$ & 0 & 0,04775 \\
\hline
\end{tabular}
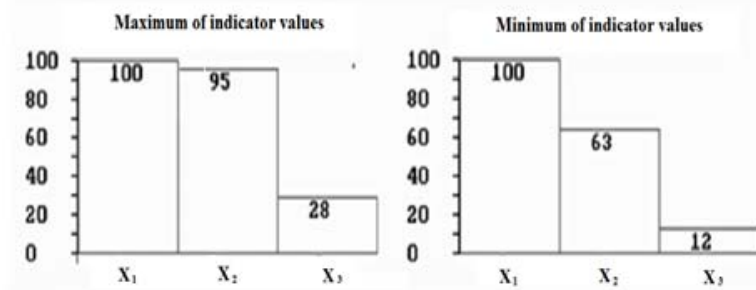

Fig. 1. Ranking the impact of variable factors on the indicator (soil filtration coefficient)

In the area minimum indicator values, where the dependencies are the most significant, the degree of influence of the discharge pressure decreased slightly. The degree of the time factor influence in the considered factor space has decreased to the limits that are not significant from an engineering point of view.

These rankings can be interpreted as follows:
- Bentonite concentration in the mortar plays
most important role for the following reasons: the conditions of the experiments carried out have enabled the most complete way to explore this relationship in the framework of selected factor space, which is confirmed by the nature of the graph shown in Fig. 2; composition of the mortar does play a major role in the arrangement of protective shields.

- From a physical point of view, the degree of influence of pressure on impervious properties is quite high, as the supply pressure of the mortar directly affects the amount of bentonite injected into the soil.

- Duration of mortar supply factor is not significant from an engineering point of view on the role of the monitoring indicator within the selected experimental conditions. 
Fig. 2 shows graphs of the indicator from each of variable factors.

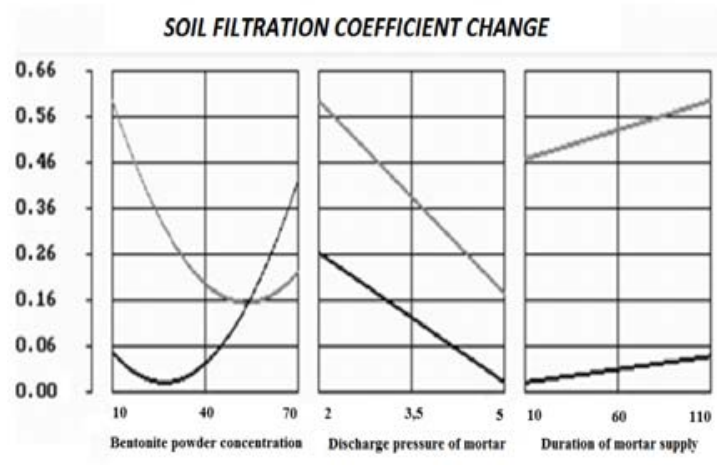

Fig. 2. Curves of the indicator dependences from the factors

The nature of the graph of the soil filtration coefficient from bentonite concentration can be called close to parabolic. In this case, the extremum of this curve is vividly shown and is within $X_{1}=(0,4 \ldots 0,5)$ in minimum indicator area, whereas it is within $X_{1}=(0,6,0,7)$ in maxima zone. It can be said that for the conditions studied in the experiments, it was possible to identify the optimal conditions for bentonite powder concentration. When translating into full-scale parameters, the most effective mortar in the minima zone would contain the amount of bentonite within $22 . .25$ grams per liter, in the area of the maxima $58 . .61$ grams per liter.

The dependence of soil filtration coefficient from the discharge pressure of mortar is inversely proportional. The angle of the line to the horizontal is sufficiently sharp, therefore we can assume that the data points belong to the parabolic nature of the curve with a peak, not included in considered factor space. In this case, used pressure values are not the highest possible from a technical point of view and may be adjusted upward during the further study.

The effect of duration of mortar supply on the indicator value is directly proportional. Limits of soil filtration coefficient changes are quite small for time variation, so you can conclude that the dependency, which follows from the obtained data, is not enough meaningful from an engineering point of view. However, under natural conditions, long duration of injection will undoubtedly affect the soil filtration coefficient of the protective shield to the reduction. The reason for this discrepancy may be due to imperfect experimental conditions.
Nature of the dependence obtained in the zone of high and low values of indicator are close. It should be noted that dependences obtained in the zone of the low values of indicator must be taken as highly significant. This is due to the ultimate goal of the experiments which is to determine the conditions under which the soil filtration coefficient of the anti-contagious shield will meet the specified conditions for water-proof resistance.

\section{Originality}

Defined patterns of influence of technological factors (supply pressure, injection time and the characteristics of injection solutions compositions) on the screen filtration coefficient.

\section{Practical value}

The practical significance of the results is the development of technologies for new methods of protection against contamination of underground space in the absence of water pressure in the soil with the solids from the use of injection technology.

\section{Conclusions}

Conducted laboratory tests allowed determination of the soil filtration values at different levels of technological factors values.

1. Experimental statistical dependency built by regression analysis has allowed determination the nature and extent of the influence of technological factors on the filtration rate of protective shield.

2 . The biggest impact on the index has bentonite concentration in the injection mortar and the discharge pressure of mortar. Thus the optimum amount of bentonite is at the level of $22 . .25$ grams per liter and the maximum allowed pressure of the discharge. Duration of mortar supply does not noticeably affect the indicator for the chosen experimental conditions.

\section{REFERENCES}

1. Алимов, А. Г. Противофильтрационная защита каналов и водоемов [Текст] / А. Г. Алимов // Гидротехническое строительство. - 2008 . № 4. - С. 36-42.

2. Чернобыльская катастрофа [Текст] / НАН України: гол. ред. Баряхтар В. Г. - Київ : Наук. думка, 1995. - 560 с.

3. Бойко, Г. А. Применение тонких противофильтрационных диафрагм в условиях Белоруссии [Текст] / Г. А. Бойко, Г. Г. Азбель, 
Г. Н. Никольская // Строительство и архитектура Белоруссии. - 1980. - № 4. - С. 31.

4. Бунтман, А. Д. Об использовании противофильтрационных завес для защиты котлованов от притока грунтовых вод [Текст] / А. Д. Бунтман // Энергетическое строительство. - 1978. - № 2. - C. 86-87.

5. Завальный, А. П. Мероприятия по охране подземных вод при эксплуатации накопителей промышленных отходов [Текст] / А. П. Завальный // Вісник Харківського національного університету імені В. М. Карамзіна. - Харків, 2013. - № 1084. - C. 217-223.

6. Пат. 2015248 С1 Российская Федерация, МПК5 Е 02 Д 3/12. Способ создания противофильтрационной завесы в лессовом грунте [Текст] / В. И. Осипов, С. Д. Филимонов, Б. Н. Мельников, Е. В. Кайль. - Заявл. 27.12.91; опубл. 30.06.94.

7. Пат. 2206663 C1 Российская Федерация, МПК7 Е 02 D 5/56, 5/20, 7/22. Способ возведения ограждающей противофильтрационной инженерно-защитной конструкции (варианты) [Текст] / А. Н. Басиев, М. В. Зелов, А. Г. Икусов. - Заявл. 21.12.2001; опубл. 20.06.2003.

8. Пат. 2347034 С1 Российская Федерация, МПК Е 02 В 3/16. Способ защиты водных ресурсов с помощью горизонтальных (межпластовых) противофильтрационных завес и технология их сооружения [Текст] / Ю. В. Пономаренко,
А. А. Изотов, В. С. Кузькин, Н. А. Клименко. Заявл. 30.07.2007; опубл. 20.02.2009, Бюл. № 5.

9. Пат. $2375580 \mathrm{C} 1$ Российская Федерация, МКИ Е 21 F 17/00, E 02 D 31/00. Способ сооружения подземной непроницаемой завесы [Текст] / М. Н. Климентов, А. Н. Петин, С. В. Сергеев, В. С. Дрямов, Ю. В. Пономаренко. - Заявл. 01.08.2008 ; опубл. 10.12.2009, Бюл. № 8.

10. Пат. 2316068 C1 Российская Федерация, МПК G 21 F 9/20. Способ защиты природных вод от радиоактивных и токсичных веществ из хранилищ жидких отходов [Текст] / Е. В. Захарова, Е. П. Каймин, Л. И. Констатинова, А. А. Зубков и др. - Заявл. 16.03.2006; опубл. 27.01.2008.

11. Пат. 2211283 C1 Российская Федерация, МПК7 Е 02 D 5/56, 5/20, 7/22. Способ возведения противофильтрационной инженерно-защитной конструкции [Текст] / А. Н. Басиев, М. В. Зелов, А. Г. Икусов. - Заявл. 21.12.2001; опубл. 27.08.2003.

12. Вознесенский, В. А. Статистические методы планирования эксперимента в техникоэкономических исследованиях [Текст] / В. А. Вознесенский. - 2-ое изд. - Москва : Финансы и статистика, 1981. - 263 с.

13. Вознесенский, В. А. Численные методы решения строительно-технологических задач на ЭВМ [Текст] / В. А. Вознесенский, Т. В. Ляшенко, Б. Л. Огарков. - Київ : Вища школа, 1989. $327 \mathrm{c}$.

\section{О. І. МЕНЕЙЛЮК ${ }^{1 *}$, А. Ф. ПЕТРОВСЬКИЙ ${ }^{2}$, О. О. БОРИСОВ ${ }^{3}$, І. Н. БАБІЙ ${ }^{4}$}

\footnotetext{
${ }^{1 *}$ Кафедра технології будівельного виробництва, Одеська державна академія будівництва та архітектури, вул. Дідріхсона, 4, Одеса, Україна, 65029, тел. +38 (048) 72361 51, ел. пошта pr.mai@mail.ru, ORCID 0000-0002-1007-309X

${ }^{2}$ Кафедра технології будівельного виробництва, Одеська державна академія будівництва та архітектури, вул. Дідріхсона, 4, Одеса, Україна, 65029, ел. пошта paf2012@ukr.net, ORCID 0000-0001-9548-1959

${ }^{3}$ Кафедра технології будівельного виробництва, Одеська державна академія будівництва та архітектури, вул. Дідріхсона, 4, Одеса, Україна, 65029, тел. +38 (094) 94920 83, ел. пошта etinvest@gmail.com, ORCID 0000-0001-6930-3243

${ }^{4}$ Кафедра технології будівельного виробництва, Одеська державна академія будівництва та архітектури, вул. Дідріхсона, 4, Одеса, Україна, 65029, тел. +38 (094) 99409 69, ел. пошта igor_babiy76@mail.ru, ORCID 0000-0001-8650-1751
}

\section{ЗАЛЕЖНІСТЬ КОЕФІЦІЕНА ФІЛЬТРАЦІЇ ГРУНТУ ВІД ПРИЙНЯТИХ ТЕХНОЛОГІЧНИХ РІШЕНЬ}

Мета. Метою даного дослідження є побудова експериментальних і статистичних залежностей коефіцієнта фільтрації захисного екрану, утвореного за допомогою горизонтально-спрямованого буріння, від технологічних факторів. Методика. Синтез, аналіз, математичні методи. Результати. Аналітичні і графічні залежності коефіцієнта фільтрації грунту від наступних технологічних факторів: тривалість ін'єкції, за допомогою якої створюється протифільтраційний екран, концентрація бентонітового порошку на одиницю об'єму твердіння будівельного розчину і тиску нагнітання (подачі) цього розчину в грунт. Наукова новизна. Визначено закономірності впливу технологічних факторів (тиск, час ін'єкції та характеристики розчинів для ін'єкцій) на коефіцієнт фільтрації екрана. Практична значимість. Практичної значимістю результатів є 
розробка нової технології захисту підземного простору від забруднення в грунтах з твердими включеннями i відсутністю водотривкого шару на досяжній глибині.

Ключові слова: протифільтраційні захисні екрани; горизонтально-спрямоване буріння; бентоніт; коефіцієнт фільтрації грунту; експериментально-статистичне моделювання
А. И. МЕНЕЙЛЮК ${ }^{1 *}$, А. Ф. ПЕТРОВСКИЙ ${ }^{2}$, А. А. БОРИСОВ 3 , И. Н. БАБИЙ ${ }^{4}$
${ }^{1 *}$ Кафедра технологии строительного производства, Одесская государственная академия строительства и архитектуры, ул. Дидрихсона, 4, Одесса, Украина, 65029, тел. +38 (048) 72361 51, эл. почта pr.mai@mail.ru,
ORCID 0000-0002-1007-309X
${ }^{2}$ Кафедра технологии строительного производства, Одесская государственная академия строительства и архитектуры, ул. Дидрихсона, 4, Одесса, Украина, 65029, эл. почта paf2012@ukr.net, ORCID 0000-0001-9548-1959
${ }^{3}$ Кафедра технологии строительного производства, Одесская государственная академия строительства и архитектуры, ул. Дидрихсона, 4, Одесса, Украина, 65029, тел. .+38 (094) 94920 83, эл. почта etinvest@gmail.com, ORCID 0000-0001-6930-3243
${ }^{4}$ Кафедра технологии строительного производства, Одесская государственная академия строительства и архитектуры, ул. Дидрихсона, 4, Одесса, Украина, 65029, тел. +38 (094) 99409 69, эл. почта igor_babiy76@mail.ru, ORCID 0000-0001-8650-1751

\section{ЗАВИСИМОСТЬ КОЭФФИЦИЕНТА ФИЛЬТРАЦИИ ГРУНТА ОТ ПРИНЯТЫХ ТЕХНОЛОГИЧЕСКИХ РЕШЕНИЙ}

Цель. Целью данного исследования является построение экспериментальных и статистических зависимостей коэффициента фильтрации защитного экрана, образованного при помощи горизонтальнонаправленного бурения, от технологических факторов. Методика. Синтез, анализ, математические методы. Результаты. Аналитические и графические зависимости коэффициента фильтрации грунта от следующих технологических факторов: продолжительность инъекции, с помощью которой создается противофильтрационный экран, концентрация бентонитового порошка на единицу объема твердения строительного раствора и давления нагнетания (подачи) этого раствора в грунт. Научная новизна. Определены закономерности влияния технологических факторов (давление, время инъекции и характеристики растворов для инъекций) на коэффициент фильтрации экрана. Практическая значимость. Практической значимостью результатов является разработка новой технологии защиты подземного пространства от загрязнения в грунтах с твердыми включениями и отсутствием водоупорного слоя на досягаемой глубине.

Ключевые слова: противофильтрационные защитные экраны; горизонтально-направленное бурение; бентонит; коэффициент фильтрации почвы; экспериментальное статистическое моделирование.

\section{REFERENCES}

1. Alimov A. G. Protivofiltratsionnaya zashchita kanalov i vodoemov [Protection impervious canals and reservoirs]. Gidrotekhnicheskoe stroitelstvo - Hydraulic engineering, 2008, no. 4, pp. 36-42.

2. Chernobylskaya katastrofa [Chernobyl disaster]. NAN Ukraine. gol. red. Barjahtar V. G. Kyjiv, Naukova dumka Publ., 1995. 560 p.

3. Boyko G. A., Azbel G. G., Nikolskaya G. N. Primenenie tonkikh protivofiltratsionnykh diafragm v usloviyakh Belorussii [The use of thin anti-filtration diaphragms in the conditions of Belarus]. Stroitelstvo $i$ arkhitektura Belorussii - Construction and Architecture of Belarus, 1980, no. 4, p. 31.

4. Butman A. D. Ob ispolzovanii protivofiltratsionnykh zaves dlya zashchity kotlovanov ot pritoka gruntovykh $\operatorname{vod}[\mathrm{On}$ the use of impervious curtain to protect the pits from groundwater inflow]. Energeticheskoe stroitelstvo - Power Engineering construction, 1978, no. 2, pp. 86-87.

5. Zavalniy A. P. Meropriyatiya po okhrane podzemnykh vod pri ekspluatatsii nakopiteley promyshlennykh otkhodov [Measures to protect groundwater in the operation of industrial waste storage]. Visnik Kharkivskogo natsionalnogo universitetu imeni V. M. Karamzina [Bulletin of Kharkiv National University named V. N. Karamzin], 2013, no. 1084, pp. 217-223.

6. Osipov V. I., Filimonov S. D., Melnikov B. N., Kayl Ye. V. Sposob sozdaniya protivofiltratsionnoy zavesy v lessovom grunte [A method for creating grout curtain in the loess soils] Patent 2015248 S1 RF, MPK5 E 02 D $3 / 12$ 
7. Basiev A. N., Zelov M. V., Ikusov A. G. Sposob vozvedeniya ograzhdayushchey protivofiltratsionnoy inzhenerno-zashchitnoy konstruktsii (varianty) [A method of erecting fencing of an anti-protection engineering design (options)] Patent 2206663 S1 RF, MPK7 E 02 D 5/56, 5/20, 7/22

8. Ponomarenko Yu. V., Izotov A. A., Kuzkin V. S., Klimenko N. A. Sposob zashchity vodnykh resursov s pomoshchyu gorizontalnykh (mezhplastovykh) protivofiltratsionnykh zaves i tekhnologiya ikh sooruzheniya [The method of water resources protection by horizontal (interstratal) impervious veils and the technology of their construction] Patent 2347034 S1 RF, MPK E 02 V 3/16

9. Klimentov M. N., Petin A. N., Sergeev S. V., Dryamov V. S., Ponomarenko Yu. V. Sposob sooruzheniya podzemnoy nepronitsaemoy zavesy [A method of construction of an underground impermeable curtains] Patent 2375580 S1 RF, MKI E 21 F 17/00, E 02 D 31/00

10. Zaharova E. V., Kaymin E. P., Konstantinova L. I., Zubkov A. A. Sposob zashchity prirodnykh vod ot radioaktivnykh i toksichnykh veshchestv iz khranilishch zhidkikh otkhodov [A method of protecting natural water from radioactive and toxic substances from the storage of liquid waste] Patent 2316068 S1 RF, MPK G $21 \mathrm{~F} 9 / 20$

11. Basiev A. N., Zelov M. V., Ikusov A. G. Sposob vozvedeniya protivofiltratsionnoy inzhenerno-zashchitnoy konstruktsii [The method of erection of an anti-protection engineering design] Patent 2211283 S1 RF, MPK7 E 02 D 5/56, 5/20, 7/22

12. Voznesenskiy V. A. Statisticheskie metody planirovaniya eksperimenta $v$ tekhniko-ekonomicheskikh issledovaniyakh [Statistical methods for experiment planning in technical and economic studies]. Moskow, Finansy i statistika Publ., 1981. 263 p.

13. Voznesenskiy V. A., Lyashenko T. V., Ogarkov B. L. Chislennye metody resheniya stroitelnotekhnologicheskikh zadach na EVM [Numerical methods for solving construction and technological problems on a computer]. Kyjiv, Vyshha shkola, 1989. 327 p.

Prof. V. A. Halushko, D. Sc. (Technical, Ukraine) and Prof. V. D. Petrenko, D. Sc. (Technical, Ukraine) recommended this article to be published.

Received: Sept. 01, 2016.

Accepted: Sept. 26, 2016. 